\title{
The English Mercurie Hoax and the Early History of the Newspaper
}

\section{Markman Ellis, QMUL}

[Pre-publication accepted draft to be published in Book History in 2019.]

In 1794 the Scottish antiquarian George Chalmers (1742-1825) undertook research into the origin of newspapers, "those pleasant vehicles of instruction, those entertaining companions of our mornings" for his biography of the Scottish publisher and scholar Thomas Ruddiman (1764-1757). After assessing the historical evidence, he declared that the first newspaper, which he defined as a regularly printed gazette of news, was English.

It may gratify our national pride to be told, that mankind are indebted to the wisdom of Elizabeth and the prudence of Burleigh for the first news-paper. The epoch of the Spanish Armada is also the epoch of a genuine news-paper. In the British Museum, there are several news-papers, which had been printed while the Spanish fleet was in the English Channel, during the year 1588. It was a wise policy, to prevent, during a moment of general anxiety, the danger of false reports, by publishing real information. And the earliest news-paper is entitled, THE ENGLISH MERGURIE, which, by Authority, was "imprinted at London by Christopher Barker, her Highnesses printer, 1588". 1

Although Chalmers noted some oddities about this example (it was printed in "Roman, not in black, letter" and had certain anachronisms), his discovery was celebrated in literary journals and magazines. ${ }^{2}$ Over the following decades, it was accepted as authoritative in a series of reference works, beginning with the fifth edition of Isaac Disraeli's Curiosities of Literature (1807), ${ }^{3}$ and thereafter the fourth volume of John Nichols's Literary Anecdotes of the Eighteenth Century (1812), ${ }^{4}$ Johann Beckmann's Concise History of Ancient Institutions (1823); 5 and from there in various encyclopædias including Encyclopedia Londinensis (1820), ${ }^{6}$ Encyclopaedia Americana (1832), ${ }^{7}$ Brockhaus's Conversations-Lexikon (1832), ${ }^{8}$ and Encyclopaedia Metropolitana (1845). ${ }^{9}$

There was only one problem with this patriotic discovery: it was a hoax. In 1839 The English Mercurie was exposed as a fake by Thomas Watts (1811-1869), Assistant Keeper of Printed Books at the British Museum. His published Letter to Antonio Panizzi Esq Keeper of the Printed Books in the British Museum (dated 16 November 1839) declared that "the claims of the English to the invention of printed Newspapers are unfortunately of no validity, and that the 'earliest Newspaper' in the Museum is an imposture". Rather than merely repeating Chalmers's claim, he had examined the item himself. "On the book being brought, I had not examined it two minutes, before, to my surprise, I was forced to conclude that the whole was a forgery". Consulting with his colleagues, John Winter Jones and Antonio Panizzi, they noticed various "marks of unauthenticity" and declared it was impossible that the printing was from 1588. The English Mercurie was, he concluded, "an imposition". ${ }^{10}$

When he returned to the topic of this "spurious production" a decade later, in an article for the Gentleman's Magazine, he was able to identify the author as Philip Yorke, second earl of Hardwicke (1720-1790), from his handwriting on accompanying manuscripts. He also noted that the mercuries were mentioned in the printed but unpublished Catalogue of the Manuscripts in the Possession of the Earl of Hardwicke, compiled by William Coxe in 1794.11 Watts noted that Yorke's manuscripts had emendations by Thomas Birch (1705-1766), in whose papers the mercuries were archived. Watts concluded, somewhat ruefully, that Birch (one of the founders of the British Museum) was not "the intended dupe of the mystification", but was actually "one of the parties engaged in carrying it out". He observed that The English Mercurie had "no pretension to literary beauties" and, in mitigation of his illustrious perpetrators, thought that it "seems never to have been brought forward by its authors with a view of deceiving the public". In conclusion he stated: "What was the object of the English Mercury is not easy to settle". ${ }^{12}$

This article seeks to answer Thomas Watts's question. His attribution was correct: the three printed examples of The English Mercurie dated 1588 were written by Philip Yorke in 1744, and printed, but not published, by the bookseller James Bettenham, through the agency of the Rev. Thomas Birch. As well as the three printed mercuries, Watts found four in manuscript, 
including two that were not printed, making five distinct mercuries in total. ${ }^{13}$ Watts's attribution in 1850 rested on identifying Yorke's handwriting, some samples of which were in Birch's papers. In 1914 D. T. B. Wood (Deputy Keeper of the Manuscripts Department, British Museum) corroborated Watts's claim by research in the Hardwicke Papers, which had only come to the British Museum in 1899, and as such had been unavailable to Watts. ${ }^{14}$ Wood's article, which referred to Yorke's fake newspapers as "Armada mercuries", has been almost entirely overlooked by subsequent scholars of newspaper history. ${ }^{15}$ This article returns to the unpublished Hardwicke and Birch papers in the British Library to develop a full account of the origin, composition, purpose, and reception of The English Mercurie in the circle of Philip Yorke and Thomas Birch in the early 1740s. It argues that The English Mercurie emerged as part of a serious engagement by Yorke with the history of the Spanish Armada crisis of 1588, and out of the coincident research by Birch and Yorke into early newspapers. More broadly, this article will discuss The English Mercurie within the Hardwicke circle's wider historical practices, particularly their emphasis on the use of original documents in manuscript and print, and in relation to their work on the history of the newspaper in Britain.

Chalmers had encountered The English Mercurie in his research for his history of the newspaper in Britain, the first such attempt. Subsequently, Joad Raymond suggests, newspaper history developed "between about 1850 and about 1880" in parallel narratives across Europe, each adopting a Whiggish approach that tried to identify which imprint had priority. ${ }^{16}$ This mode of scholarship depended on a definition of the newspaper (printed, public, and periodically produced) predicated on its later history. David Randall suggested The New Tydings out of Italie are Not Yet Come (2 December 1620) as the earliest surviving English-language newspaper. ${ }^{17}$ Other sources note Joseph Carolus's Relation aller Fürnemmen und gedenckwïrdigen Historien (Strasbourg, 1605-) as the earliest surviving weekly newspaper in Europe; or Mercury Gallobelgicus, written in Latin and printed semi-annually from 1592 in Cologne..$^{18}$ More recent approaches to newspaper history, such as those of Joad Raymond, and the many contributors to Raymond and Moxham's Newes Networks in Early Modern Europe (2016), have largely obviated the question of determining "the first newspaper" by transforming the Whiggish approach into an enquiry organised around "news" as information traced through the international networks it creates, disseminated in the manuscript or print formats (newsletter, news pamphlet, newsbook, newspaper) appropriate to the diverse patterns of consumption of each network. In this context, the fact that The English Mercurie is not "the first newspaper" is less important than what its composition, dissemination, and preservation can tell us about the place of the newspaper in the practices of history writing in the Hardwicke circle.

\section{Athenian Letters and the Hardwicke Gircle}

In the early 1740s Thomas Birch was a clergyman and man of letters attached loosely to the Yorke family through the patronage of Philip Yorke the elder, Lord Chancellor and Baron Hardwicke (1690-1764). Birch had been appointed editor in 1733, along with John Peter Bernard and John Lockman, of The General Dictionary, Historical and Critical (10 volumes, published between 1734 and 1741), an ambitious project to translate and expand Pierre Bayle's Dictionnaire Historique et Critique (1697). ${ }^{19}$ Birch was subsequently elected Fellow of the Royal Society in 1734, and Fellow of the Society of Antiquaries in 1735. It was as a scholar that Birch first met Philip Yorke the younger in 1740, around the time he came down from Corpus Christi College, Cambridge, not quite twenty years old. ${ }^{20}$ Yorke, as he is referred to in this article, had been granted a very lucrative sinecure as Teller of the Exchequer in 1738, through his father's influence. On 22 May 1740 he married Lady Jemima Campbell (1722-1797), a beautiful, young, wealthy, and well-educated heiress, who was suo jure (in her own right) Marchioness de Grey. The young couple set up house at Wrest Park, his wife's country estate in Bedfordshire, inherited from her grandfather Henry Grey, Duke of Kent (1671-1740). In 1741, Yorke entered Parliament as MP for Reigate in Kent, and was elected Fellow of the Royal Society. Birch's fortunes were henceforth closely entwined with Yorke, Lady Grey and Lord Hardwicke. Birch subsequently rose through the church to hold several livings, including the wealthy City parish 
of St. Margaret Pattens, which allowed him the leisure to pursue his literary and historical interests. He was elected Secretary to the Royal Society in 1752 and made a founder Trustee of the British Museum in 1753. In the same period, Yorke improved his country estate, interested himself in historical scholarship, and developed his parliamentary career, where he kept an important diary of debates in both houses between December 1743 and April 1745.21 Yorke's father was created the Earl of Hardwicke in 1754, and Yorke inherited his father's title, fortune, and country estate at Wimpole in Cambridgeshire in 1764. Yorke and Birch were at the center of an intellectual coterie now known as the "Hardwicke circle", whose activities and cultural politics were very influential in the Royal Society in the mid-eighteenth century. ${ }^{22}$ There they exercised their influence through control of the higher offices, in the reform of the Royal Society's administrative procedures, and in the maintenance of its characteristic forms of sociability.

This prosopography perhaps makes it harder to understand how Yorke and Birch produced the sham English Mercurie in 1744. The immediate precursor and formal influence was a large-scale collaborative writing project, the Athenian Letters (1741-43), written and coordinated by Philip and Charles Yorke, with the assistance of Birch and a wider group of Cambridge scholars. This was an innovative work of epistolary fiction, retelling the history of the Peloponnesian War between Greece and Sparta in the fifth century BC, familiar from Thucydides and Plutarch. It took the form of letters written between Cleander, an agent of the King of Persia, to ministers and friends at home in the Persian court. It is a bravura combination of fiction-writing with serious scholarship, influenced by Oriental "spy" fiction such as Marana's Letters Writ by a Turkish Spy (1684-1686) or Montesquieu's Persian Letters (1721). In addition to the two Yorke brothers, additional contributions were made by a group of fellow students, scholars, and friends, including Henry Coventry, John Green, John Heaton, William Heberden, John Lawry, George Henry Rooke, Samuel Salter, Catherine Talbot, and Daniel Wray. The Athenian Letters might have met with considerable popular success and literary influence, had it been published. ${ }^{23}$ But instead, Birch prepared the manuscript for the press in complete secrecy, and Philip Yorke instructed James Bettenham of St. John's Lane to print only twelve copies: a form of coterie dissemination known as print without publication, practised especially by authors among the polite elite. Lord Shaftesbury had cautioned against print publication in his "Soliloquy; or, Advice to an Author" (1711), arguing that the uncontrolled dissemination of printed texts exposed an author to criticism of all kinds by persons driven by nefarious motives such as faction, flattery, jealousy, or mercenary interest. Instead, Shaftesbury suggested private modes of dissemination, such as the circulation of a manuscript among a coterie of friends. But he also recognised that printed text was easier to read and its copies were more accurate, so he further concluded that multiple printed copies could be drawn off a press for coterie dissemination, the printer acting only as an amanuensis. ${ }^{24}$ Shaftesbury practised and promoted this costly mode of print without publication, and was emulated by Yorke in Athenian Letters.

The connection between the fiction of Athenian Letters and the project of The English Mercurie has been recognised for some time. Watts, for example, pointed to "a sort of family resemblance" between the two texts in 1850,25 and before that, in 1840, the Secretary of the British Museum, Sir Henry Ellis, had noted the connection between "the originator of the Athenian Letters, and the fabricator of the English Mercuries". ${ }^{26}$ The common trait is their provision of historical evidence (letters, newspapers) in a format that was both anachronistic and fictional. There are numerous differences between the two texts, notably that of scale and fictionality. Athenian Letters is a prose fiction, akin to an epistolary novel, from classical Greece: an exuberantly fictional combination. ${ }^{27}$ A collection of letters, it is framed by an elaborate prefatory narrative explaining how they had come to the modern public, a literary commonplace known as "the discovered manuscript" trope. This claimed that a fair copy of the manuscript letters, translated into Spanish, had been left to the English consul at Algiers, translated from the Persian by a Jewish scholar called Moses ben Meshobab, who had discovered them in a Moroccan monastery at Fez. ${ }^{28}$ The "epistemological self-consciousness" of the discovered manuscript trope was, through its familiarity to eighteenth-century readers, both a form of historicism and fictionality. ${ }^{29}$ By contrast, The English Mercurie was 
unaccompanied by any prefatory discovery narrative, and as a printed newspaper from 1588, was a more subtle test of reader credulity: "credible" but "precocious", as Joad Raymond says. ${ }^{30}$ In the early 1740s, Birch was engaged in a series of large-scale history projects. First among these was the publication in 1742, in seven vast folio volumes, of the state papers of John Thurloe, secretary of state during the English Republic and Protectorate. ${ }^{31}$ After that, Birch took on the life of Robert Boyle, a substantial 458-page biography, published in Boyle's Works (1744). ${ }^{32}$ Birch was also undertaking research for Nicholas Tindal's continuation of his translation of the Huguenot historian Paul de Rapin Thoyras's History of England (1726-1731). Tindal's continuation was planned to bring Rapin up to the late 1730s, but his progress was slow. Birch was appointed to "Collect the Materials" for the history, especially documentary evidence in transcripts and originals, and to organise them clearly for Tindal to "compile"; in addition he provided drafts of connecting narrative. ${ }^{33}$ Yorke was intrigued and excited by Birch's research and writing in these various history projects in the period 1740-43.

Yorke had his own interests in historical scholarship. In 1741 he published an essay entitled "On the Acta Diurna of the old Romans" in the annual volume of Edward Cave's monthly The Gentleman's Magazine (Volume X for 1740, published 1741). ${ }^{34}$ His essay was prefaced by a paragraph attributed to Samuel Johnson: the essay itself is attributed here to Yorke for the first time, though it has been sometimes erroneously attributed to Johnson. ${ }^{35}$ The essay was written while Yorke was at Cambridge in 1739, where it circulated in manuscript "not only entirely new but entirely Humorous \& Entertaining" — amongst his friends, including Thomas Clarke and John Lawry. ${ }^{36}$ With his brother Charles's encouragement and through the agency of Birch, Yorke sent the draft for the essay to Cave in January 1741.37 Yorke's essay concerns the Acta Diurna ["daily acts"], a miscellaneous set of manuscript "newsletters" written in Rome during the period 59 BC-AD 222 that provided an account of diverse events, including those related to government, private civilian matters, military affairs, and religious observances. Under the rule of Julius Caesar, they were for a brief period made public and copied widely; more usually they were part of the private machinery of the Roman state. Yorke's account of the Acta Diurna builds on the seventeenth-century antiquarian scholarship of classical culture, but makes an important innovation by considering them as part of the history of newspapers. His essay is a scholarly discussion, fully referenced with footnotes, but also makes some effort to translate this discourse into the congenial English prose appropriate for the Gentleman's Magazine. His classical sources include Livy, Cicero, and Suetonius, but focus on two substantial translations of Acta (published in $169 \mathrm{BC}$ and $63 \mathrm{BC}$ ) from the text of the Dutch antiquarian Stephanus Vinandus Pighius (1520-1604). ${ }^{38}$ In his essay, Yorke's tone is urbane and worldly, appropriate to an occasional essay in the spectatorial mode, as when he quips that "Tully [Cicero], would have made a bad Figure in a modern Coffee-house Conversation". 39

Yorke's essay opens with an analysis of the role of the newspaper in the everyday life of the modern city. Newspapers and other "Collections of Intelligence periodically published", he says, afford for the citizens of a modern state the materials for "Discourse and Speculation". As such, they

contribute very much to the Emolument of Society; their Cheapness brings them into universal Use; their Variety adapts them to every one's Taste: The Scholar instructs himself with Advice from the literary World; the Soldier makes a Campaign in safety, and censures the Conduct of Generals without Fear of being punished for Mutiny; the Politician, inspired by the Fumes of the Coffee-pot, unravels the knotty Intrigues of the Ministers; the industrious Merchant observes the Course of Trade and Navigation; and the honest Shop-keeper nods over the Account of a Robbery and the Prices of Goods till his Pipe is out. 40

Yorke's portrait of the utility of newspapers is affectionate and worldly, but also reflects the Hardwicke circle's wider curiosity about the history and materiality of information and news. His analysis of what Uriel Heyd has called the "news culture" of the period argues that news, and its discussion, is a record of public affairs, but also shapes that record. ${ }^{41}$ In Yorke's estimation, news is a commodity and an entertainment shared across a wide spectrum of society, from the politician and scholar to the merchant and shopkeeper, brought together in a broad 
and common debate, that in some senses looks forward to notions of "public opinion". Yorke's essay, published in 1741, has been described as being amongst the first historical enquiries into the history of the newspaper. ${ }^{42}$

Yorke's analogy between the Acta Diurna and the newspaper reflects his location in a period in which the volume and variety of newspapers had increased significantly. As Hannah Barker argues, there had been a "dramatic increase in the number of newspapers produced in England" in the period after the lapse of the Licensing Act in 1695. As well as an increase in the number of titles, there was also "striking increase" in newspaper circulation, from 2.4 million copies in 1712, to 7.3 million by 1750 (based on Treasury receipts for the newspaper stamps used as a record of tax paid). ${ }^{43}$ To adapt Ann Blair's formulation, the new flood of news was a kind of "information overload", in the face of which readers developed new systems for managing information flows. ${ }^{44}$ Beginning in 1740 , and continuing to 1766, Birch wrote a regular hebdomadal newsletter to Yorke: a 'weekly despatch' of 'literary \& political speculations' from the political, literary and scientific worlds. 45 Birch's "Weekly Letter" functioned as a mechanism for controlling and summarising the flood of news. Both men were avid consumers of contemporary newspapers, including ministerial Daily Gazetteer and the antiministerial London Evening Post; Birch also refers to reading the Utrecht, Amsterdam, and Hague gazettes when he can get them. ${ }^{46}$ In addition, Yorke subscribed to several manuscript newsletter services. ${ }^{47}$ Both men saw the newspaper as an active subject of their scholarly curiosity, as a source of primary and documentary historical evidence. Both collected early manuscript newsletters ${ }^{48}$ and printed newspapers. ${ }^{49}$ In October 1742, for example, Yorke commissioned Birch to search for a volume of The London Gazette that he was missing from his collection, so as "to compleat my Gazettes of Ch[arles] the 2d's reign". ${ }^{0}$ Birch and Yorke enjoyed the quotidian world of newspaper reading, in which the news - and the paper it was printed on - was a commercial and ephemeral focus of sociable debate. But they also saw the newspaper as a documentary source of primary historical information, and as such, as an object worthy of scholarly and antiquarian enquiry.

\section{3: Yorke's Armada History}

In 1743 Yorke returned to the idea of historical writing. He wrote to Birch in May 1743 that "I have a Project in my Head but I know not whether I shall carry it into execution, of writing un morceau d"histoire". ${ }^{51}$ History was commonly regarded as one of the higher literary pursuits, but Yorke was uncertain as to an appropriate topic. Birch argued in 1749 that the study of history is "next to that of the great and unalterable principles of Morality and Religion, the basis of all sound judgment and right conduct". ${ }^{52}$ Birch's declaration that history was located in a moral context of truth-telling aligns his practice with seventeenth-century historiography, which, in Justin Champion's analysis, was embedded "in the didactic ideals of humanist rhetoric". ${ }^{33}$ As such, Birch continued, nothing "is more suitable" than history "to the higher stations of life", even though high "rank and fortune" is "attended with so many temptations and avocations". Reading, studying, or even better, writing history was the best preparation for higher office in the service of the state. History, Birch wrote,

has at once the particular advantage of being the best qualification for public business, and the more general one of opening and enlarging the mind by a thorough knowledge of mankind in all their situations, mazes, and recesses, superior to the imaginary theories of mere philosophers, and exempt from the inconveniencies, which accompany real practice, and personal experience. ${ }^{54}$

Yorke had received an education at Cambridge appropriate for the study of history. But he was also busy with his family life and estate, his government position, and his office as a member of parliament. These commitments suggested that the type of history he might tackle would need to be the sort that could be accomplished in his study. He was either disinclined, or lacked the ability, to undertake the kind of scholarly labor that he most valued, of which Birch was a specialist. 
The period of history Yorke decided on was the reign of Queen Elizabeth, specifically the Spanish Armada crisis of 1588. Writing to Birch on 27 May 1743, Yorke said "I have pitch'd upon the Defeat of the Sp: Armada in 88 as a shining part of a very active Reign, to describe". ${ }^{55}$ Yorke explains that the historical interest of the topic for him lay in the actions and policy of the Queen, her ministers and the military, in a period of crisis and international rivalry that threatened the existence of Britain and the Church of England.

I wd premise the general state of affairs both at home \& abroad, before it was taken in hand, the Politics of Q. Elizabeth both with regard to Spain from the beginning of her Reign till yt time. You know one while she was upon friendly terms with Phillip the $2^{\text {nd }}$. I wd likewise intersperse particular Characters of the great Men in her Court \& Army; and make but short work with the fighting part; for a dry journal of a sea fight is extreamly cold. 56

But he was not sure of his decision.

- Let me know your opinion of this? Can you recommend a more untrodden path in our History or a more engaging one. Think a little, \& write me word, for I am present in ye right state for taking advice. ${ }^{57}$

Despite Yorke's anxieties, Birch replied with enthusiasm:

Your historical Design gives me the highest Pleasure; the Plan you intend to pursue is a very judicious one, \& resembles those of my favourite Sallust; \& the Subject is one of the most interesting in the whole Compass of our Annals; \& deserves that excellent Hand, which has done such ample justice to an important period of our Athenian History, \& made us less regret the Defects of the Antient Histories. Proceed therefore with your usual Vigour. ${ }^{58}$

Birch encouraged Yorke's historical ambition, and reinforced the connection between the new project and Athenian Letters, which, he ventured, had supplied the "Defects" of classical history. Yorke replied that he was "glad you approve my Historical Plan" ${ }^{59}$ Daniel Wray, a friend and contributor to Athenian Letters in Cambridge, known ironically as "the Licenser" within the circle, also approved Yorke's plan. ${ }^{60}$

Over the rest of the summer, Yorke clarified his intentions. In a letter to Birch on 5 June 1743, Yorke established that his primary goal was a study of the great men of state operating effectively and with virtue in a time of national crisis, rather than a record of naval events and tactics. But he also identified "three facts relating to the affair which I want more light about than I have at present":

The first is the manner in which the design was discovered to be ag[ain]st England: Burnet \& Welwood are rather apocryphal authorities. The next, as you observe, is the true key to the Prince of Parma's Conduct, which certainly gave umbrage to the Spanish Court. The $3^{\text {rd }}$ the draining the Bank of Genoa. ${ }^{61}$

This list of scholarly questions show that Yorke's project was to be a serious work of historical writing. His first question was about the extent of Elizabeth's espionage in Europe; the second about the conduct of the Spanish land forces in France; and the third about the role of English merchants in disrupting the financing of the victualing of the Spanish fleet. These were significant problems in the extant historiography: all three were mentioned in the earlier histories of James Welwood and Gilbert Burnet, as Yorke notes. ${ }^{62}$

In planning his history, Yorke faced a more practical problem: how to find and gain access to the books and manuscripts he needed to inform his study. His letters to Birch over the coming months return repeatedly to his search for "materials", particularly little-known books, pamphlets, and manuscripts which would allow him to say something new. Birch had been quick to offer his assistance, writing of his "Readiness to point out to you such Materials, as my own or my Friends collections will afford". ${ }^{63}$ Birch suggests that Yorke would acquire his "materials" for writing by reading printed books in the libraries and collections of his friends and family. Yorke had access to his own library at Wrest Park, inherited by Jemima Yorke from her grandfather the duke of Kent, to his father's library at Wimpole, and the Hardwicke family 
library at the St. James's Square townhouse. But these libraries, acquired relatively recently lacked catalogues and formal systems of organisation, and although Yorke had commissioned John Lawry to make a catalogue of the library at Wrest, Lawry had made little progress. ${ }^{64}$ Birch's own library also supplied some materials, and his expertise was called on to suggest further resources. So, for example, on 5 June, Yorke wrote to Birch: "I will be looking out other materials: there is pretty good choice here, but Strype is wanting, wch is a necessary Book: cannot you provide me with that Tome of his collections, wch included 1588? I shall then be well furnished with the printed accts of ye Æra." ${ }^{65}$ Yorke asks here to borrow the appropriate volume - the third - of John Strype's Annals of the Reformation and Establishment of [...] the Church of England (1723). 66 The book was to be sent to St. James's Square "with a direction to forward it to me by the Carrier" to Wrest.

Yorke's historical method also impelled him to search for contemporary printed accounts of events. Over the following months, Yorke sent a stream of requests for additional printed books, including some nearly contemporary with the Armada crisis 67 and others of more modern provenance. ${ }^{68} \mathrm{He}$ was frustrated that two recently published collections of Elizabethan state papers only extended to the early part of her reign: Samuel Haynes's volume of state papers from 1542 to 1570 from the collection of William Cecil (Lord Burghley) at Hatfield, 69 and Patrick Forbes's volume of "public transactions" of the reign of Queen Elizabeth in state repositories. ${ }^{70}$ As both projects implied continuations, Yorke urged Birch throughout 1743 to enquire into their progress, and if possible to secure an advance view of the second volumes, and if not, to get access to their materials. He was unsuccessful in both cases, and neither project made any headway for many years. ${ }^{71}$

Yorke also requested that Birch help him find manuscript resources: "some Mss anecdotes would be highly acceptable, \& I wish you may be able to assist me in yt point". ${ }^{72}$ Birch wrote promisingly that "Lord Burghley's Papers at Hatfield would be of vast use, where, I am told, it appears, that the Prince of Parma was not faithful to his Spanish Interests at that Crisis." 73 But access to these resources was difficult, and using them was time-consuming. Yorke especially desired access to the Hatfield collection, especially if Birch would do it for him: "I wish yr all-prying eyes cd take a peep for me into the Library at Hatfield, with wch my piece cannot be compleat". ${ }^{74}$ But Birch had proposed merely to "point out" materials, and as the months passed, it became clear that Yorke wanted Birch to offer more: to locate, find, buy, transcribe, abstract. and "methodize" or organise the materials.

In June Yorke wrote that he was pleased with his "laying in materials", but even so, he worried that he had failed to solve all the problems he had identified. ${ }^{75}$ Two weeks later, on 29 June, he complained that "I am afraid I must defer making any great progress in that scheme till a less busy time". ${ }^{76}$ Nonetheless in his letter of 24 July 1743 , Yorke proudly announced to Birch "I enclose a general Plan of my Invasion, \& have finished the Introduction to it, proposing to go on with the Remainder at my leisure, for I am in no haste to finish it, but shall reserve it as a relief from business of a dryer nature." 77 Yorke sent him the plan on a separate sheet of paper, folded and slightly smaller than his usual half-folio, entitled "History of the Sp: Invasion in the Year 1588. - Plan of the Work". ${ }^{78}$ This is significant enough to warrant quotation at length:

Introduction: importance and remarkable nature of the Enterprize, from its general design and origin, greatness of the preparations, consequences if it had succeeded, extraordinary circumstances that attended it.

1. The conduct of Q: Eliz: and the Sp: Court from her accession, with regard to each other, considered, particularly in the Treaty of Cambray, the proposal of marriage from K: Philip, the Treaty of Edinburgh, \& the Low Country Troubles. The general Views \& Characters of Ph: and Eliz: Those of the Ld Burleigh, Ld Leicester, Sec: Walsingham at Large \& likewise of the principal Spanish Ministers, P. of Parma, D. of [Sido]nia, etc.: the particular State of Affairs in both Kingdoms at the time this Expedition was taken in hand. Debates about it in the Sp: Council. Preparations made for it in the different Ports of the Sp: Monarchy. Choice of a General \& chief Officers, Duke of Medina and Recalde. Encouragement of the design given by the Pope. Manner in 
which the design was discovered by Q. E. her Counter Preparations; draining the Bank of Genoa; institution of the Council of War, the [illegible] Regulations. Orders with regard to the Militia. Naval and Land Armaments. Characters of the chief Land \& Sea Officers slightly touched, Lord Ad: Sir W[alter] R[alegh], Sir F[rances] D[rake] etc. Account of the Neg: at Bourbourg - broke off by the appearance of the Sp: Armado. [127v-128r] Particulars of the actions on the Coast of France \& England between the two Fleets; total dispersion of the Spanish; impudent Falsehood of Mendoza. Compliments between our Q: \& K: James. Rejoicings made for our happy Deliverance - medals struck, etc.

The plan ended with a list of "Authors to be consulted", which reprised his research of the previous months. The project focuses on Anglo-Spanish relations in the late sixteenth century, as Yorke had suggested, not just the Armada itself. Birch replied encouragingly: "The Plan of your History is such an one, that I shall be very impatient for the Execution of it". ${ }^{79}$ But by midSeptember 1743, Yorke was encountering problems: "I am at some stand in the Invasion for want of new materials, where the old are defective". ${ }^{80}$ He continued to pursue news of Haynes and Forbes, and asked Birch again for any relevant manuscript resources, such as those Birch might discover from his friend Francis Say (1690-1748), librarian of the Queen's Library in St. James's. ${ }^{81}$

Yorke's project for his "Invasion history", as envisaged in 1743, was to be a serious work of historical scholarship and writing, to be pursued through his engagement with original documents and correspondence, printed and manuscript, official and private. As noted above, Birch and Yorke held history in high repute as an object of study, especially for those in the higher stations of life. The craft of history writing was important to them, as was history's moral imperative. In Justin Champion's analysis, "History was written to explain, justify and, most of all, to persuade. The past was not resurrected for 'its own sake', but in order to display the moral rectitude of a particular set of facts. The importance of 'true history' for 'true principles' cannot be underscored too heavily." 82 Yorke's proposed Armada history found a close fit with Birch's Whig history writing, such as his work for the continuation of Rapin's History or his Thurloe State Papers. Birch and Yorke's claim to priority over their rivals, they believed, was methodological as much as interpretative. That which made their scholarship distinctive, authoritative, and impartial, Birch argued, was their higher regard for primary evidence. This claim was in part a commonplace, as historians since the sixteenth century had made similar claims about superiority of their own treatment of historical evidence. ${ }^{83}$ But Birch especially found a Whig resonance in his renovation of documentary evidence and the apparatus of scholarship, especially his archival recovery of the correspondence of the officers of the state, secret service intelligence, small pamphlets and satires, and newsbooks and newspapers. Furthermore, Birch, and later Yorke, undertook not only to recover this primary material for their scholarship, but to have such "state papers" published, either in their own editorial projects, or with their encouragement, by others.

By finding new "materials", as he called them, Yorke intended to bring new insight onto the problems of statecraft and decision-making provoked by the Spanish invasion threat. It was not his purpose to disturb the event's totemic location within Whig historiography, such as that offered in Rapin's history. In this way, he would confirm Elizabeth's care and diligence in attending to the crisis, show that her ministers of state and military commanders were of the highest quality and integrity, and demonstrate that the Navy and its officers fought with valor, despite their forces being inferior in size and number. ${ }^{84}$ The focus on the conduct of statesmen in a time of national crisis further reflected Yorke's contemporary political concerns: from the Hanoverian succession, to the fallout from the end of Walpole's ministry, and the threat posed by French support for Jacobite invasion in the context of the War of the Austrian Succession. These fears were justified: a large-scale French invasion force assembled in the channel in February 1744, although the transports at Dunkirk were severely disrupted by bad weather and the threat dissipated. ${ }^{85}$ Yorke's parliamentary journal recorded the transactions of the government's response in detail.

Yorke's choice of topic may also have been inspired by a specific and local parliamentary influence. As he was well aware, the chamber of the House of Lords, in the mid- 
eighteenth century, was hung with the great Armada tapestries, woven in the mid-1590s to celebrate the victory. ${ }^{86}$ The tapestries were celebrated in a set of engravings published by John Pine in 1739, of which Lord Hardwicke was a subscriber. ${ }^{87}$ The Armada tapestries were themselves a prompt for rhetorical celebrations of the liberty of the British nation. Thomas Herring wrote to Yorke that Lord Chesterfield, in a speech attacking Walpole's ministry in March 1739 in the presence of the Chancellor Lord Hardwicke, invoked the Armada tapestries: "One of his Arts was to turn ye eyes of ye audience upon ye Tapestry, \& bid them remember ye transactions of that immortal Navy \& then to ask, whether there were any History Looms at work now - He hoped not, $w^{\text {th }}$ great emphasis". ${ }^{88}$ An Armada history would help promote Yorke as a loyal Hanoverian and Whig, but to write it, he would need more material.

\section{4: Yorke's Pivot}

In 1744 Parliament broke up on 11 May, and ten days later, on 21 May, Yorke and his family made their seasonal move back to Wrest, taking Birch with them for a vacation. On 2 June Birch returned to London, and on 9 June he recommenced his weekly letter ${ }^{89}$ Birch was at this period still occupied with collecting materials for Tindal's continuation of Rapin's History of England, which had now progressed to the beginning of Queen Anne's reign in 1702.

Yorke's pivot away from an orthodox Armada history was signalled when he wrote to Birch on 15 July 1744 that "Not having at present leisure or inclination to draw up a terse \& compleat account of the Invasion in 88, I have amused my self with throwing some of the more public Occurrences relating to it, into the form of a News Paper of that time." The phrasing of Yorke's rationale is redolent of gentlemanly leisure. He proposes to cast the established events in the form of "a News Paper of that time", recalling the practice of the Athenian Letters. Yorke continued to Birch:

- if you think the design is tolerably well executed I wish you would have 3 or 4 Copies only, taken off at Bettenhams Press \& send them me as soon as they are finished: when I will transmit to you the remainder. I think they should be printed like one of the old News Books \& on Paper very little if at all better. - If you chuse one of the Copies as a Perquisite for the trouble of correcting you are welcome to it, but I would have the thing remain a Secret between us two.- tho' after all in case you should think that le jeu ne vaut pas la Chandelle [the game is not worth the candle], I shall readily acquiesce..$^{90}$

James Bettenham (c.1683-1774) was a well-respected printer who had worked with many eminent booksellers, and was one of three investors in William Caslon's new type foundry. Bettenham's shop was in St John's-lane, Clerkenwell, where Birch had been born and raised. He had gained Yorke's trust having printed, in secret, the twelve copies of Athenian Letters in 1740 and 1742. For The English Mercurie, Yorke reduced the number of copies to "three or four", allowing Birch to keep one for himself (presumably the copy in his archive, Add MS 4106). The type and paper were chosen to emulate "one of the old News Books". Yorke's term "news book" describes "a small newspaper", and, first used in 1643, was in common parlance in the 1650s and 1660s. It suggests that the kind of newspaper that The English Mercurie proposed to emulate was a civil-war period printed serial weekly periodical pamphlet, along the lines of Mercurius Civicus (1643-1646) or The Kingdomes Weekly Intelligencer (1643-1649). In fact the outcome was less orthodox.

Secrecy was important to Yorke's game, as he was habitually reluctant to court public notice. Although Birch had commented derogatorily about "modest Authors, who have an Aversion to the seeing themselves in print", Yorke's dislike of publicity was not uncommon amongst aristocratic writers. ${ }^{91}$ His solution, as with the Athenian Letters, was coterie dissemination by print without publication, following the Shaftesbury model. The production of the mercuries was kept secret even from the household at Wrest: Yorke added that "If you have occasion to touch on this matter in yr weekly Dispatch, let it be in a separate paper, for I generally read the other to the good company". ${ }^{92}$ It was important to Yorke that his friends and family should be kept in the dark, so that the joke could be played on them. 
Design issues were prominent in Birch"s reply to Yorke on 21 July:

I have put into Bettenham's hands the two Journals, which you transmitted to me in your last Letter, \& have settled on the Form of the Impression, which you will easily conceive ought not to be in the least remarkable for the Elegance of the Types or the Beauty of the Paper. I have directed it to be done in quarto, because that is the size of the oldest News-papers, that I have seen; \& have order'd a due mixture of the black Gothic Letter to be made use of, especially in the Titles. I expect a proof of the papers every day..$^{93}$

Birch's decision to print in quarto reflected his decision to imitate the earliest English newspapers he knew, those of the 1640s, although the manuscript copy sent to him by Yorke was written on folio sheets in two columns (more like a mid-eighteenth century newspaper). Birch's decision to print the title in "black Gothic Letter" recalled the early printed German newsbooks such as Relation aller Fürnemmen und gedenckwïrdigen Historien (1605). The English Mercurie was thus a bastard hybrid, recalling both English newsbooks of the 1640s and elements from the earlier European tradition. Yorke was keen that his mercuries should be as free from errors as possible. In a note received by Birch on 24 July, Yorke requested corrections: "I believe it should be Duke instead of Prince of Parma all along, \& that the Foreign Advices should be ranged according to their Dates. Any other little slips I beg you would correct." "94 "Duke" was more accurate, but it must have been too late, as Parma remained a "Prince" in the printed mercuries. ${ }^{95}$

The first printed copies were received at Wrest by the end of July. Yorke wrote on 29 July that he had "receiv'd together with your weekly Letter, 3 of the Elizabethan Gazettes, wch, as to the form \& manner of the impression, gave me entire satisfaction". Yorke was happy with Birch's editorial labors. But in the next sentence, he suggests he was already tired of the project: "I believe it will [please] you to hear that after the $4^{\text {th }}$ is dispatched, you are like to be troubled with no more of them". ${ }^{96}$ Yorke's enthusiasm had waned before the fourth and fifth mercury (No. 53 and 54) were even printed. The mercuries are not mentioned again in his correspondence with Birch until 20 February 1745, when he asked about the bill for printing them: "I must once more remind you of bringing me on Monday Bettenham's Bill for printing the mercuries, wch I wd willingly discharge". ${ }^{97}$ The archive does not record what Yorke paid.

If The English Mercurie was a joke whose intended audience was Yorke's family and friends, it is disappointing but unsurprising that there is no record of how it was received. Yorke and Lady Grey had many visitors at Wrest that summer, among them a progression of scholarly gentlemen including Charles Yorke, Daniel Wray, and Thomas Edwards, as well as his father and mother, Philip Lord Hardwicke and Lady Hardwicke. ${ }^{98}$ These visitors left no explicit commentary on The English Mercurie. However, Yorke's friend Daniel Wray, in assessing Yorke's skills as a correspondent on 11 November 1744, commented: "Do not therefore suppose that I demand Shams \& Banters of you". The phrasing is obscure: a "sham" is a counterfeit or spurious imitation, and a "banter" is a merry jest intended to ridicule a subject or person. The timing of this comment suggests that he might have meant The English Mercurie, and that he did not approve of such jests. Wray suggested Yorke should write instead "in the manner of those Great Writers; and give me the Original Papers \& Authentic Details of your transactions as a Parish-reformer, a Reader of Folios, and above all a Planter of Pear \& Fig-trees" - the latter probably referring to Yorke's ambitious plans for the garden at Wrest. 99

I have described the inception and production of The English Mercurie in such detail to show that it began as, and was embedded in, serious scholarship. Yorke was deeply interested in modern history writing, especially in the use of original documents. There are two conclusions about The English Mercurie to be drawn here. The first is that it is history writing by another method, making a complex and sophisticated contribution to eighteenth-century thinking about Elizabethan history. The second is that, though it has been derided since the 1840s as a hoax newspaper, it also has an important role in the history of the newspaper. As Joad Raymond has argued, Yorke's "contrivance", both its discovery by Chalmers in 1794 and its exposure as a hoax by Watts in 1839, contributed to the Victorian enterprise of a "scholarly history" of the newspaper. "The cozening of Chalmers became the founding moment of their 
scholarship", he argues, as Victorian historians "worried at the dangers of error and on the immorality of deceiving posterity". ${ }^{100}$ To follow the history of The English Mercurie's deception requires a closer inspection of the mercuries. ${ }^{101}$

\section{The English Mercurie in Manuscript and Print}

Birch's archive preserves five separate numbers of The English Mercurie, comprising numbers 50 to 54, dated irregularly over 19 weeks between 23 July and 24 November 1588, comprising three printed and four manuscript items. For two numbers there is both print and manuscript (51 and 54), two exist in manuscript alone (52 and 53), and one in print alone (50). Each printed mercury has standardized paratext: on the first page a title, page number in square brackets, and issue number, and on the reverse a colophon. The title in the printed copies is uniform: The English Mercurie. Published by AUTHORITIE, for the Prevention offalse Reportes, with the words "English Mercurie" in black letter. The manuscripts offer more variation, with the preferred spelling being "English Mercury"; No. 53 gives an alternative title of "The State Intelligencer". ${ }^{102}$ The title "English Mercurie" is not an inappropriate name: early newsbooks and newsletters in Europe used a wide variety of titles, including "coranto", "aviso", "gazette", or "mercury", both in manuscript and print. ${ }^{103}$

The five texts of Yorke's English Mercurie in manuscript and print made a concerted attempt to dissimulate an early newspaper, albeit one of a somewhat later date than 1588 . They reported the Armada crisis by recording intelligence received by the Queen's ministers in London, such as her principal secretary Francis Walsingham, from different correspondents and locations, such as the Lord High Admiral Charles Howard, 1st Earl of Nottingham, of the Ark Royal (No. 50 dated July 23). Numbers 51 and 52 include a naval journal that gives an eyewitness account of the events in the Channel. Foreign correspondents allow Yorke to articulate the Spanish and Catholic perspectives, such as the report in Number 51 from an English secret agent in Spain, detailing the extent of the "Invincible Armado (as it is called)", its commanding officers, and their optimism: "Most People are very sanguine about the Successe of it". 104 The most significant action of the crisis, the battle at Gravelines, is reported at the end of the unprinted number 53 when Admiral Howard announced "the important news of the entire defeat \& dispersion of the Sp: Armado" in the Straits of Calais on 28 July. 105 The last mercury in the sequence, number 54 , is given a date nearly three months after the previous issue, Monday 24 November 1588, and describes the "solemne generall Thanksgivinge for the Successes obtayned against the Spanish Armado". ${ }^{106}$ The final section of No. 54, titled "Advertisement of Bookes", lists five contemporary books "All ymprinted, and to be solde by Jhon Field and Christ. Barker" [sic]. ${ }^{107}$

In formal terms, Yorke's prose imitates the circumstantial reports, written to the moment, of Elizabethan intelligence. Yorke adopts the lexical conceit of old English spelling for many words. He also does some important imaginative work, inhabiting the present instant of the news event, as if the outcome is not yet known. The first sighting of the "one hundred and fifty Ships" of the Armada uses the rhetoric of wonder: he notes "severall of them called Galleons and Galleasses" which "are of a Size never seene before in our Seas" and "appeare on the Surface of the Water like floatinge Castles". A similar imaginative leap can be seen in his rival accounts of the same events from English and Spanish points of view. Yorke does not invent spurious or incredible events: his accounts of the sea fights or French politics are rigorously restricted to what is known to have happened, with no unexpected or new evidence, no "smoking gun". The hoax is directed at the formal properties of early newspapers, not at the "news" contained therein. The English Mercurie is a fake newspaper, not fake news.

There are, nonetheless, inconsistencies and problems in Yorke's English Mercurie that give away its polychronistic status, between 1744 and 1588. These problems are found both in the printed document's production, and in historiographical inconsistencies. Watts's letter to Panizzi in 1839 provides an insightful and thorough guide to these. There are two aspects, he says, that "arouse suspicion in the printed numbers": the form of the type; and the numbering of the issues and the pages therein. ${ }^{108}$ The most prominent material signal of The English Mercurie's eighteenth-century origins is its Caslon font, probably the most famous and distinctive 
modern English type of the period -- closely associated with Bettenham, as he was one of its primary investors. ${ }^{109}$ Furthermore, printers in the 1580s made no distinction between the letters $i$ and $j$, or $u$ and $v$, and used $v v$ for $w$; yet in The English Mercurie the modern conventions for these letters are maintained consistently. ${ }^{110}$ Watts also observed that the manuscript copies of numbers 51, 52, and 53 use modern spelling, which has been corrected (or "antiquated") to "old form" English in the printed version of number 51. In the case of the manuscript of number 54 , the corrections are made in another ink and in a different hand (identified as that of Birch). The corrections usually involve little more than adding an archaic $e$ to the end of some words: kingdom becomes kingdome, and so on. Certain words are also anachronistic or used anachronistically: the term "advertisement" used in the final number, referring to a public notice of items for commercial sale, is not noticed by the OED before 1692. Watts further suggests that it is not credible that news of the events at sea could reach London as quickly as The English Mercurie claims. As an example, Watts questions whether news of Francis Drake taking the galleon St. Francis on the evening of 21 July, and bringing the captured ship into Portsmouth on the next morning, could reach Whitehall by 23 July in time for publication in a newspaper dated the same day. ${ }^{111}$ Watts determines that this "truly remarkable" speed is not credible.

\section{On Hoaxes and Hoaxers}

Much of the discussion of The English Mercurie by Watts, both in 1839 and 1850, is structured around the exposure of a hoax, a narrative embedded in a moral framework. At first, Birch is preserved from blame, as a clergyman, FRS, and founding figure of the British Museum. In the letter to Panizzi in 1839, Watts says that "It cannot for a moment be supposed that Dr. Birch was accessary to the deception: his character wholly forbids it." Watts suggests that the preservation of the manuscripts with the printed mercuries show that Birch took "reasonable care that others should not be deceived". Watts suggested a series of potential "literary forgers" of the period who might have been responsible: Thomas Chatterton, George Steevens, and William Rufus Chetwood (not usually counted as a forger), though he determined that their handwriting and literary styles did not match. ${ }^{112}$

Only six weeks after Watts published his open letter to Panizzi, Sir Henry Ellis, Principal Librarian of the British Museum, had exposed Yorke as the author of the mercuries in a private letter, citing a match of his handwriting, which had been identified by John Cates, superintendent of the reading room. ${ }^{113}$ Cates further concluded that the manuscript emendations were by Birch, who thus was now included amongst those guilty of the forgery. Other authorities revised their accounts accordingly. In the twelfth edition of The Curiosities of Literature (1841), Isaac Disraeli (1766-1848) added a postscript revising his account of The English Mercurie, stating that it was a "literary imposture": "The fact is, the whole is a modern forgery; for which Birch, preserving it among his papers, has not assigned either the occasion or the motive. I am inclined to suspect that it was a jeu d'esprit of historical antiquarianism, concocted by himself and his friends the Yorkes." 114 Thomas Carlyle (1795-1881), writing to Watts in 1849, perhaps as he was writing the piece for the Gentleman's Magazine, said "I know not what degree of fraud you have clearly brought home to Birch; but should, unless the facts peremptorily forbade, tend strongly to consider him, poor ditch-water soul, as rather the dupe than the cheat in any case of hoax." 115 Newspaper historians were less generous, perhaps because, as apologists for the moral status of newspapers, more was at stake. Frederick Knight Hunt (1814-1854) followed the account of the "forgery" in Watts to "fix the commission of the literary crime (for crime it certainly is) upon the second Lord Hardwicke" (Yorke). Birch is also attacked: "The English Mercurie forms a part of Dr Birch's MSS., and the detection of this fraud throws a painful doubt over the authenticity of other documents which have passed as genuine into our national library, on the authority of that collector." 116

Both Birch and Yorke were, after this pronouncement, regularly accused of perpetrating the crime of forgery. James Grant (1802-1879) saw the "iniquitous forgery" as conclusive evidence of Birch's moral fall: "no language can stigmatize in sufficiently strong 
terms the conduct of Dr Birch. He succeeded in practising a grave imposture on the world for considerably over half a century". ${ }^{117}$ Although his own discussion of The English Mercurie suggests he had not inspected them first-hand, Grant amplifies the seriousness of the issue: "The detection of historical errors like this has a very painful and injurious effect when reading the annals of any age or country. It has a tendency to inspire us with more or less of distrust as to the truth of that which we most earnestly desire to believe." 118 As Disraeli had suggested in 1841, the whole English Mercurie affair was a "memorable instance of the danger incurred by historians from forged documents; and proof that multiplied authorities add no strength to evidence, when all are to be traced to a single source". ${ }^{119}$

Watts thought The English Mercurie had "no pretension to literary beauties": it is not fine writing, he argued, and as a newspaper, did not emulate or dissimulate a literary genre. ${ }^{120}$ This is both overstated and ideologically overdetermined. Writing for a newspaper is an act of literary creativity, like any other, with its own set of expectations and characteristics, even if such writing lacked literary prestige. That lack of prestige was underpinned by the morally suspect nature of the hoax, of which newspapers were particularly adept in the Victorian period. ${ }^{121}$ The eighteenth-century literary culture was also very interested in hoaxes and shams, such as those of James Macpherson and Thomas Chatterton; an interest reflected in the sizable body of recent critical writing analyzing the literary qualities of forgery and deception. ${ }^{122}$

An important context for The English Mercurie hoax was the culture of writing games undertaken in the polite, genteel, and leisured literary culture at Wrest by Yorke,Jemima Yorke, and their guests. ${ }^{123}$ These games included poetry-writing competitions, especially sociable exchanges of occasional sonnets, and the collaborative composition of ironic and satirical fictions, including essays in imitation of the Spectator, a "Mock-Heroic Historical Romance", and of course Athenian Letters. ${ }^{124}$ The Yorkes also undertook elaborate architectural follies in the garden at Wrest. In 1743 Daniel Wray proposed a "Bam", or hoax, "about a design for erecting a Mithraic Altar in yr Gardens at Rest". ${ }^{225}$ By 1748 Wray's altar, adorned with mysterious runic inscriptions, had been completed in a quiet corner of the garden, where visitors might encounter it as if for the first time. Jemima Yorke, in a letter to her friend Catherine Talbot, described a visit by two antiquarians from Cambridge, during which one was fooled by "the Persian altar". ${ }^{126}$ Like these polite hoaxes, The English Mercurie anticipated its own exposure: as Kate Loveman argues, "to be truly successful a sham had eventually to be recognised as such". 127 Part of the pleasure of a hoax is the feeling that readers experience after they have recognised a sham for what it is, and can examine its working parts in a new light. At Wrest, sociable literary games took place alongside serious and large-scale antiquarian and historical scholarship.

When Watts discussed the "hoax" in 1850, he proposed that Chalmers had found The English Mercurie from its mention in the catalogue of Yorke's manuscripts, prepared by William Coxe and printed but not published in 1794. This is a red herring. Coxe's catalogue does list, under "Journals and Periodicals", the "English Mercuries published by Authority in Queen Elizabeth, King James, and Charles the First's Times", 128 an entry that suggests that there were additional mercuries from later reigns. However, Chalmers, and Watts after him, had no way to ascertain what these were, as the Hardwicke collection was still in the libraries at Wrest and Wimpole. The British Museum acquired the Hardwicke manuscript collection from Wimpole in 1899, after the Historic Manuscripts Commission had determined it was "of national interest". ${ }^{29}$ There is no mention of the Elizabethan or later mercuries in the sale catalogue, or in the collection acquired by the British Museum. Furthermore, Chalmers cannot have used the Hardwicke catalogue to find The English Mercurie in 1794, as that catalogue was not a guide to the Birch Collection in the British Museum, which is where the mercuries were located.

Chalmers, however, did have the opportunity to use the British Museum catalogue to the Birch papers. The mercuries were listed in the first manuscript catalogue, prepared by the Rev. Westley Hall in 1772 (Add Ms 4478A), which noted at No. 225 "The English Mercuries published by Authoritie in 1588". ${ }^{130}$ However, Chalmers is more likely to have used the printed catalogue that superseded Hall's list, prepared by Samuel Ayscough in 1782, which listed the mercuries as "Copies of several English mercuries (news papers) published in 1588", where they were included in a volume by Birch numbered 4106, described as "A collection of letters and 
papers relating to state affairs, chiefly copied, some copied by Dr. Birch". When Ayscough compiled the Catalogue of Birch's papers in 1782, he found them "in the greatest confusion, being chiefly written on loose papers, and only tied up in bundles, without any regard to subject or connection". He worked to "reduce them to some order and regularity", arranging them into volumes, so that "the curious and learned to find them placed in some connection". ${ }^{131}$ These volumes have remained largely unchanged since that time: Add MS 4106 is now no different from what Chalmers read in 1794, and Watts in 1839. The English Mercurie, both manuscript drafts and printed items, is foliated in sequence and numbered in ink 29-42 (later altered in pencil to 27-40, sequence unchanged). Chalmers would have encountered the printed mercuries, with their telltale Caslon font, bound together with their manuscript drafts, written in Yorke's neat eighteenth-century handwriting, as listed in the library catalogue. Disraeli described how he had seen Chalmers - "that laborious researcher" - in the 1790s "busied among the long dusty shelves of our periodical papers" in the British Museum. His "alledged discovery" of The English Mercurie was, Disraeli said, a "blunder", especially as Chalmers would have also seen "the original, with all its corrections, before it was sent to the press, written on paper of modern fabric". ${ }^{132}$ Whatever his rationale, Chalmers's mistake made a claim about the mercuries that created a hoax narrative that was activated in 1839 by Watts's revelation.

\section{Conclusion}

Thomas Watts determined that The English Mercurie was a hoax and a forgery, undertaken by Yorke, with the assistance of Birch and Bettenham. This was a powerful accusation, as forgery was as strongly stigmatized by historians in 1839 as it was in 1744, as Birch and Yorke testify in their letters. In 1742 the historian Thomas Carte (1686-1754), a Tory nonjuror, attracted Birch's ire after the publication of his pamphlet, A Full Answer to the Letter from a By-stander, which defended the probity of Stuart government. ${ }^{133}$ Carte had been writing, since 1738, a pro-Stuart history of England designed as a corrective to Rapin, that he eventually published 1747-55.134 Birch was profoundly hostile to Carte's historical project, and in the case of the pamphlet, focussed his attack on Carte's scholarship, describing him as "the most flagrant Imposter, that ever appear"d in print". A Full Answer, Birch continued, was "a gross panegyric upon the reign of the Stuarts, \& as gross a Libel upon all the Times since the Revolution. His pretended Facts are supported by an amazing assurance for want of real Evidence, tho' he pretends to cite Acts of Parliament, \& Journals of the House of Commons". ${ }^{135}$ Yorke concurred: the author of such "gross misrepresentations" must be "the most impudent of mortals". ${ }^{136}$ On Saturday 23 September Birch had confronted Carte in a coffeehouse "before a large Company", telling him "my sentiments of his pamphlet, \& the Grounds of them, in very plain terms, which would have provok'd an innocent Man, but threw him into confusion". ${ }^{137}$ Subsequently Birch wrote a fortypage manuscript "stigmatizing" Carte as a "flagrant...Trader in Historical Forgery"; his manuscript may have been shown to William Pulteney and Corbyn Morris for their printed response to Carte. ${ }^{138}$ Errors in historical scholarship, especially those serving party interests, aroused a strong level of condemnation, clearly embedded in moral discourse.

What might protect Yorke from similar condemnation as "a trader in historical forgery"? The supposed immorality was mitigated by the production and dissemination of the documents, which made no claims about their origin or priority. Like many of Yorke's early productions, such as Athenian Letters, the mercuries were printed but not published. They were not intended to deceive later scholars, or to find a place in any genuine history, and were for all purposes to be kept private. They would be read within a gentlemanly culture of historical games, by a tightly-defined group of friends and family, and were not to be circulated beyond that circle. After Birch's death, a single copy of the mercuries were archived in his collection in the British Museum, where they were preserved and catalogued alongside the drafts and correspondence that explained their context.

As a fictional newspaper of 1588, The English Mercurie was an anachronism, several decades too early. As a fictional newspaper of 1744 , it was also a response to and reflection on the mid-eighteenth century expansion of the newspaper and the information explosion it was 
embedded in. Evidence in the Birch-Yorke correspondence presented here shows that The English Mercurie began life within a study of the Spanish Armada invasion crisis, for which Yorke completed extensive research. This theme had profound local resonance, given the threat of French-supported Jacobite invasion in the 1740s. Rather than the intended work of history, Yorke's only output was the mercuries. As far as he was able, Yorke did not invent historical events, and, although 156 years late, the content of the newspaper was accurate. The focus of his forgery was in this sense historiographical, in the dissimulation of a newspaper out of its historical location, reinforcing the role of the newspaper as a source of documentary evidence.

Newspapers, newsletters, and official state papers were at the heart of the Hardwicke circle's history-writing projects. Birch's history publications repeatedly began with historiographical defences in which he argued for the importance of original documents, preferred even over memoirs. Yorke's publications in later life, such Miscellaneous State Papers (1778), testify to his regard for primary historical documents. The frustration Yorke experienced in finding resources for his Armada history encouraged his interest in the collection of historical documents, especially original state papers, but also manuscript newsletters, printed newspapers, and occasional political pamphlets. This interest in the history of historical evidence is also evident in The English Mercurie. The best recent study of early newspaper historiography begins unsurprisingly with an analysis of The English Mercurie hoax. But it also itemizes Yorke's anonymous Acta Diurna essay among the significant "notes on early newspapers and their forerunners". ${ }^{139}$ In this way, Yorke was responsible for both the earliest major contributions to the history of newspapers in English, both the ironic scholarship of the Acta Diurna essay and the scholarly irony of The English Mercurie.

\section{Notes}

In preparing this paper, I am grateful for the comments and assistance of Alex Barber, Rebecca Beasley, Todd Gilman, Colin Jones, Miles Ogborn, Joad Raymond, Christopher Reid, Matt Rubery, Barbara Taylor, and the two anonymous readers for Book History. Remaining errors are mine alone.

1 George Chalmers, The Life of Thomas Ruddiman (London: printed for John Stockdale, Piccadilly; and William Laing, Edinburgh, 1794), 106.

2 "[Review] ART. XII. Chalmers's Life of Thomas Ruddiman", British Critic, 4 (July 1794): $61-66$ (6162); "The Origin and History of Newspapers", Edinburgh Magazine (November 1795): 336-40.

3 Isaac Disraeli, Curiosities of Literature, $5^{\text {th }}$ ed. (London: Printed for John Murray; Edinburgh: Archibald Constable \& Co., 1807), 2:259-62

4 John Nichols, Literary Anecdotes of the Eighteenth Century (London: for the author by Nichols, Son, and Bentley, 1812-16), 4:38.

5 Johann Beckmann, A Concise History of Ancient Institutions in Science and Mechanic Art, Inventions, and Discoveries (London: G. \& W. B. Whittaker, 1823), 219-20.

${ }^{6}$ Encyclopedia Londinensis (London: printed for the proprietor by J. Adlard, 1810-29), 17:24.

${ }^{7}$ Encyclopaedia Americana (Philadelphia: Carey and Lea, 1832), 9:253.

8 "Zeitungen und Zeitschriften", Conversations-Lexikon der neuesten Zeit und Literatur (Leipzig: F. A. Brockhaus, 1832-34), 4:1025.

9 "Newspapers", Encyclopaedia Metropolitana (London: B. Fellowes et al., 1817-1845), 9:489-93.

10 Thomas Watts, A Letter to Antonio Panizzi Esq Keeper of the Printed Books in the British Museum on the Reputed Earliest Printed Newespaper "The English Mercurie 1588" (London: William Pickering, 1839), 5-6.

${ }^{11}$ William Coxe, Catalogue of the Manuscripts in the Possession of the Earl of Hardwicke ([London?], [not published], 1794).

12 Thomas Watts, "Authorship of the Fabricated Earliest English Newspaper", Gentleman's Magazine 33 (May 1850: 485-49 (465, 486).

${ }^{13}$ British Library Add MS 4106: The English Mercurie (i) 26 July 1588, ff. 27-28; (ii) No. 50, 23 July 1588 [printed], ff. 29-30; (iii) No. 51, 26 July 1588 [printed], ff. 31-32; (iv) No. 54, 24 November 1588 [printed], ff. 33-34; (v) 28 July 1588, ff. 35-36; (vi) August 1588, ff. 37-38; (vii) 25 November 1588, ff. 39-40.

${ }^{14}$ D. T. B. Wood, "The True History of the Fabrication of the Armada Mercuries", Nineteenth Century 75 (1914): 342-54. Wood uses evidence from the Birch-Yorke "Weekly Letter", acquired by the British Museum in 1897.

15 Wood"s article is however briefly mentioned in Folke Dahl, “Amsterdam - Earliest Newspaper Centre of Western Europe", Het Boek 25:3 (1939): 161-98. 
${ }^{16}$ Joad Raymond, "News Networks", in Newes Networks in Early Moderm Europe, ed. Joad Raymond and Noah Moxham (Leiden: Brill, 2016), 102.

${ }^{17}$ David Randall, Credibility in Elizabethan and Early Stuart Military Newes (London: Pickering and Chatto, 2008), 1.

18 Paul Arblaster et al., "The Lexicons of Early Modern News", in Raymond and Moxham, Neres Networks, 71.

19 Thomas Birch, John Peter Bernard, and John Lockman (eds.), A General Dictionary, Historical and Critical, 10 vols. (London: printed by James Bettenham, for G. Strahan, J. Clarke, T. Hatchet in Cornhill et al., 1734- 1741).

20 Yorke matriculated in 1737, left without a degree in 1740, and received the degree of LLD in 1749, at which time he was also MP for Cambridgeshire (1745-54).

21 "Parliamentary Journal of the Hon. Philip Yorke, MP for Reigate for the sessions 1743-44 and 174445", Add MS 35337.

${ }_{22}$ D. P. Miller, "The 'Hardwicke circle': The Whig Supremacy and Its Demise in the 18th-century Royal Society", Notes and Records of the Royal Society 52 (1998): 73-91.

${ }^{23}$ Athenian Letters (London: printed by James Bettenham, [1741]-43).

${ }^{24}$ Anthony Ashley Cooper, Earl of Shaftesbury, "Soliloquy; or, Advice to an Author", Characteristicks of Men, Manners, Opinions, Times, $2^{\text {nd }}$ ed. ([London: printed by John Darby], 1714 [1715]), 1:303-39.

25 Thomas Watts, "Authorship of the Fabricated Earliest English Newspaper", Gentleman's Magazine, NS 33 (May 1850): 485-49

${ }^{26}$ Henry Ellis to Lord Holland, 1 January 1840, Add MS 36653/8, f. 2v.

${ }^{27}$ On the blurred boundaries between history and fiction in the period, see Karen O'Brien, "History and the Novel in Eighteenth-Century Britain", Huntington Library Quarterly, 68 (March 2005): 397-413.

${ }^{28}$ Athenian Letters, I:iv-v.

${ }^{29}$ Michael McKeon, The Origins of the English Novel, 1600-1740 (Baltimore and London: Johns Hopkins University Press, 1987), 56-57.

${ }^{30}$ Joad Raymond, "Introduction: Newspaper, Forgeries, and Histories", Prose Studies 21:2 (1998): 1.

31 John Thurloe, A Collection of the State Papers of Fohn Thurloe, Esq. (London: printed for the executor of the late Mr. Fletcher Gyles; Thomas Woodward, at the Half-Moon, between the Temple-Gates, in FleetStreet; and Charles Davis in Pater-Noster-Row, 1742).

32 Thomas Birch, The Works of the Honourable Robert Boyle (London: printed for A. Millar, 1744). The Works was published on 12 December 1743 (Daily Post, 12 December 1743).

33 Nicholas Tindal to Thomas Birch, 23 August 1743, Add MS 4319 f. 157r. William Coxe argued in 1800 that the Rapin Continuation was "published under the name of Tindal, but principally written by Dr. Birch" (Memoirs of the Life and Administration of Sir Robert Walpole, Earl of Orford [London: Printed for T. Cadell, jun. and W. Davies, 1800], xii), an opinion supported by Laird Okie, Augustan Historical Writing: Histories of England in the English Enlightenment (Lanham, MD: University Press of America, 1991), 122.

34 Philip Yorke], "On the Acta Diurna of the Old Romans", Gentleman's Magazine 10 (1740): iii-viii.

${ }^{35} \mathrm{~J}$. D. Fleeman, A Bibliography of the Works of Samuel Fohnson: Volume 1, 1731-1759 (Oxford: Clarendon Press, 2000), 53. Fleeman assesses the claim for attributing the preface and the essay on the Acta Diurna to Johnson, but concurs that only the opening paragraph is Johnson.

36 Thomas Clarke to Philip Yorke, Add MS 35605, 5 June 1739, f. 14r; John Lawry to Philip Yorke, 30 July 1739, Add MS 35605, f. 17r.

37 "An Essay on the Acta Diurna of the Old Romans", Add Ms 4458, ff. 86-93 (in Philip Yorke's handwriting, with some markup in another ink and hand, possibly Birch's). A copy of the printed essay is inserted in the first volume of the "Weekly Letter", Add Mss 35396, ff. 5-6. Charles wrote "I wish you would publish ye Acta Diurna in London as a philosopher, and then send it to me", Charles Yorke to Philip Yorke, 7 December 1740, "Sunday Evening", Add MS 35360, f. 17v. Edward Cave replied to Thomas Birch, January 10 1740/41 Add MS 4302 f. 107r.

38 Stephanus Vinandus Pighius, Annales Romanorum (Antverpiæ: ex Officina Plantiniana, apud Viduam \& Elios Ioannis Moreti, 1615), "Anni P.R.C. DLXXCV", 2:377-81; "Anni P.R.G. DCXCI", 3:328-37. Andrew Lintott, "Acta Antiquissima: A Week in the History of the Roman Republic", Papers of the British School at Rome 54 (1986): 213-28; H. L. Van Gessel, "Acta Urbis-Ancient Rome's Local Paper", International Communication Gazette 16.1 (1970): 88-104.

39 [Yorke], "On the Acta Diurna," viii, iv.

40 [Yorke], "On the Acta Diurna", iv

${ }^{41}$ Uriel Heyd, Reading Newespapers: Press and Public in Eighteenth-Century Britain and America (Oxford: Voltaire Foundation, 2012), 3 .

42 Joad Raymond, "The History of Newspapers and the History of Journalism: Two Disciplines or One?”, Media History 5:2 (1999): 223-32 (pp. 229-30) 
${ }^{43}$ Hannah Barker, Newspapers, Politics, and English Society 1695-1855 (Harlow: Longman, 1998), 29-31; Jeremy Black, The English Press in the Eighteenth Century (London: Croom Helm, 1987), 105.

${ }_{44}$ Ann Blair, "Too Much to Know": Managing Scholarly Information before the Modern Age (New Haven: Yale University Press, 2010), 3.

45 Yorke to Birch, Wimpole, 7 October 1742, Add Mss 35396, f. 75r; Yorke to Birch, Wimpole, 5 September 1742, Add Mss 35396, f. 54r. See Markman Ellis, 'Thomas Birch's 'Weekly Letter' of 'Literary Intelligence' (1741-1766): correspondence and history in the mid-eighteenth century Royal Society', Notes and Records: the Royal Society Fournal for the History of Science, 68:3 (September 20, 2014) pp. 261-278.

${ }^{46}$ Daily Gazetteer: Birch to Yorke, 27 October 1741, Add Mss 35396, ff. 35-36; Yorke to Birch, 7 October 1742, Add Mss 35396, ff. 75-76; London Evening Post: Yorke to Birch, 22 August 1745, Add Mss 35396, ff. 309-11. Dutch gazettes: Birch to Yorke, 7 September 1745, Add Mss 35396, ff. 319-20; Birch to Yorke, 24 September 1741, Add 35396, ff. 25-26r; Yorke to Birch, 12 June 1744, Add Mss 35396, ff. 199-200.

47 Christopher Reid, "Reporting by Letter: The 2nd Earl of Hardwicke and his Parliamentary Correspondents," Parliamentary History (forthcoming 2019).

${ }^{48}$ Add MS 4125 includes, for example, several series of manuscript newsletters, such as two French "nouvelles" from 1586 and 1588; 62 bifolium weekly newsletters in Italian in a variety of hands relating news of events in Venice, Rome, and Antwerp from January 1593 to February 1594; and another series of 53 from April 1597 to March 1598. Add MS 4125: "nouvelles" from Narbonne, ff. 11-12; newsletters from Venice etc., 1593-94 series, ff. 24-37, 44-156; 1597-98 series ff. 180-305 [interspersed with other items].

49 By 1757 the catalogue to Birch's own library (Add MS 4252), referred to "A Collection of the 4to Diurnals from 1646 to 1649" and "A large Collection of the Mercurius Politicus \& Publius from 1650 to 1662", Add MS 4252, f. 53v.

${ }^{50}$ Yorke to Birch, 7 October 1742, Add 35396, ff. 75-76.

51 Yorke to Birch, "Rest", 27 May 1743, 93-95, Add Mss 35396, f. 94r.

52 Thomas Birch, An Historical View of the Negotiations between the Courts of England, France, and Brussels, from the Year 1592 to 1617 (London: Printed for A. Millar, 1749), iii.

${ }^{53}$ Justin Champion, The Pillars of Priestcraft Shaken: The Church of England and Its Enemies, 1660-1730 (Cambridge: Cambridge University Press, 1992), 225.

${ }_{54}$ Birch, Historical View of the Negotiations, iii-iv.

55 Yorke to Birch, "Rest", 27 May 1743, Add Mss 35396, f. 94r-v.

56 Yorke to Birch, "Rest", 27 May 1743, Add Mss 35396, f. 94v.

57 Yorke to Birch, "Rest", 27 May 1743, Add Mss 35396, f. 94v.

${ }_{58}$ Birch to Yorke, 4 June 1743, Add Mss 35396, f. 98r.

59 Yorke to Birch, "Rest", 5 June 1743, Add Mss 35396, f. 100v.

${ }^{60}$ Birch to Yorke, 18 June 1743, Add Mss 35396, f. 108v. "Pray tell the Licenser that he has reconcil'd me to his Authority by his approbation of your Historical Design".

61 Yorke to Birch, "Rest", 5 June 1743, 100v-101r.

${ }^{62}$ James Welwood, Memoirs of the Most Material Transactions in England, for the Last Hundred Mears, Preceding the Revolution in 1688 (London: T. Goodwin, 1702), 9-10; Gilbert Burnet, Bishop Bumet's History of His Own Time (London: printed for Thomas Ward, 1724-1734), 313.

63 Birch to Yorke, 4 June 1743, Add Mss 35396, f. 98r.

64 Birch to Yorke, 18 June 1743, Add Mss 35396, f. 107r.

65 Yorke to Birch, "Rest", 5 June 1743, Add Mss 35396, f.100v.

${ }^{66}$ John Strype, Annals of the Reformation, 4 vols. (London: Tho. Edlin, 1725-1731).

${ }_{67}$ Birch (11 June 1743, Add Mss 35396, f. 103r) recommended Famiano Strada (1572-1649), the Jesuit author of De Bello Belgico decades duae (1632-1647), a pro-Spanish and pro-Catholic book on the Dutch war of independence; and Abraham Nicolas Amelot de la Houssaye (1634-1706), a French historian whose Mémoires historiques, politiques, critiques, et littéraires was published in Amsterdam in 1722. Yorke added Guido Bentivoglio's (1577-1644) Historicall Relations of the United Provinces of Flanders (1629, translated 1652). Birch also sent some unspecified "scarce Tracts relating to the Spanish Invasion, publish't about that very time" (Birch to Yorke, London, 18 June 1743, Add Mss 35396, f. 107r). Yorke also mentions a "Mss Acct of the Sp: Expedition" (Yorke to Birch, "Rest", 29 June 1743, Add Mss 35396, f. 113v).

${ }^{68}$ In addition to Rapin, Birch recommended fellow antiquarian William Oldys (1696-1761), Life of Sir Walter Ralegh (1740), and Thomas Lediard's (1685-1743) The Naval History of England (1735).

69 Samuel Haynes, Vicar of Hatfield, had published a small selection of the papers of William Cecil, Baron Burghley (1520/21-1598), the chief minister of Queen Elizabeth: A Collection of State Papers, Relating to Affairs in the Reigns of King Henry VIII, King Edward VI, Queen Mary, and Queen Elizabeth, from the Year 1542 to 1570 (London: William Bowyer, 1740). The second volume was not published until 1759, edited by William Murdin. 
${ }^{70}$ Patrick Forbes (ed.), A Full view of the Public Transactions in the Reign of Q. Elizabeth (London: printed by J. Bettenham, and sold by G. Hawkins, 1740).

${ }^{71}$ Patrick Forbes's proposed second volume was never published, and in the late 1740s Yorke purchased his manuscripts. The "Forbes Papers" were noted in Yorke's collection in Birch's Memoirs of the Reign of Queen Elizabeth, from the Year 1581 'til Her Death (1754), p. 175, and are now Add MS 4133-4146.

72 Yorke to Birch, "Rest", 5 June 1743, Add Mss 35396, f.100v.

73 Birch to Yorke, London, 4 June 1743, Add Mss 35396, f. 98r.

74 Yorke to Birch, "Rest", 19 June 1743, Add Mss 35396, f. 109v.

75 Yorke to Birch, "Rest", 19 June 1743, Add Mss 35396, f. 109v-110r.

${ }^{76}$ Yorke to Birch, "Rest", 29 June 1743, Add Mss 35396, f. 113v.

77 Yorke to Birch, "Rest", 24 July 1743, Add Mss 35396, f. 126r.

${ }^{78}$ Yorke, "History of the Sp: Invasion in the Year 1588. — Plan of the Work", Add Mss 35396, ff. 12728.

${ }^{79}$ Birch to Yorke, 30 July 1743, Add Mss 35396, f 129r.

80 Yorke to Birch, 13 September 1743, Add Mss 35396, f. 152r.

81 Yorke to Birch, 18 September 1743, ff. 156-58; Birch to Yorke, 26 September 1743, f. 159r.

${ }^{82}$ Champion, Pillars of Priestcraft Shaken, 225.

${ }^{83}$ David Womersley, "Against the Teleology of Technique", Huntington Library Quarterly 68 (March 2005): 95-108.

${ }^{84}$ Paul de Rapin de Thoyras, The History of England, trans. Nicholas Tindal, $5^{\text {th }}$ edn (London: Printed by assignment from Mr. Knapton for T. Osborne et al., 1757), 7:505.

85 Norman Longmate, Island Fortress: The Defence of Great Britain, 1603-1945 (London: Hutchison, 1991), 147-49; Jacqueline Riding, Facobites: A New History of the '45 Rebellion (London: Bloomsbury, 2017), 16-29. ${ }^{86}$ Stephen Farrell, "The Armada Tapestries in the Old Palace of Westminster", Parliamentary History, 29:3 (2010): 416-40.

${ }^{87}$ John Pine, The Tapestry Hangings of the House of Lords Representing the Several Engagements between the English and Spanish Fleets, in the Ever Memorable Year 1588 (London: John Pine, 1739).

88 Thomas Herring to Yorke, 2 March 1739, Add MS 35605, f. 11v.

${ }^{99}$ Birch "Diary", 21 May, 2 and 9 June 1744, Add MS 4478C, f. 101v.

90 Yorke to Birch, 15 July 1744, Add Mss 35396, ff. 223r-v.

91 Birch to Yorke, 30 June 1744, Add Mss 35396, f. 218 r.

92 Yorke to Birch, note endorsed by Birch "July 24 1744", Add Mss 35396, f. 226r.

93 Birch to Yorke, 21 July 1744, Add Mss 35396, f. 224r.

94 Yorke to Birch, endorsed by Birch "July 24 1744", Add Mss 35396, f. 226r.

${ }_{95}$ Alexander Farnese (1545-1592) was Duke of Parma, Piacenza, and Castro from 1586 to 1592, and Governor of the Spanish Netherlands from 1578 to 1592. Camden, amongst others, styles him a prince (William Camden, The History Of The Most Renowned and Victorious Princess Elizabeth, Late Queen of England, $4^{\text {th }}$ ed. (London: Bentley, 1688), Book III, p. 404.

96 Yorke to Birch, 29 July 1744, Add Mss 35396, 229r.

97 Yorke to Birch [not posted, endorsed in Birch"s hand: "Wednesday Febr. 20 1744/45"], Add Mss 35396, f. 279r.

98 Philip Lord Hardwicke to Yorke, 13 October 1744, Add MS 35351, ff. 49r-v.

99 Wray to Yorke, 11 November 1744, Add MS 35401, ff. 40r-v.

${ }^{100}$ Raymond, "Introduction: Newspaper, Forgeries, and Histories", 3-4.

${ }^{101}$ Frederick Knight Hunt, The Fourth Estate: Contributions Towards a History of Newespapers, and of the Liberty of the Press (1850; repr. London: Routledge/Thoemmes Press, 1998), 1:302.

102 English Mercurie [53], Add MS 4106, ff. 37-38.

103 Paul Arblaster et al., "The Lexicons of Early Modern News", in Raymond and Moxham (eds.), Neres Networks, 64-101.

${ }^{104}$ English Mercurie, 51, p. 7.

105 Add MS 4106, ff. 37-38.

${ }^{106}$ English Mercurie, 54, p. 3.

${ }^{107}$ English Mercurie, 54, p. 4.

108 Watts, Letter to Panizzi, 7.

109 James Mosley, "Caslon, William, the elder (1692-1766)", Oxford Dictionary of National Biography.

110 Watts, Letter to Panizzi, 7-8.

${ }_{111}$ English Mercurie, No. 50, pp. 1-2.

112 Watts, Letter to Panizzi, 14-15.

${ }^{113}$ Henry Ellis to Lord Holland, 1 January 1840, Add MS 36653/8, f. 2v.

${ }^{114}$ Isaac Disraeli, Curiosities of Literature, 12th ed. (London: E. Moxon, 1843), p. ix. 
115 Thomas Carlyle to Thomas Watts, 6 February 1849, in The Collected Letters of Thomas and Jane Welsh Carlyle, ed. Charles Richard Sanders (Durham: Duke University Press, 1970-), 23:227-28.

116 Hunt, The Fourth Estate, 1:302.

${ }^{117}$ James Grant, The Newspaper Press; Its Origin--Progress--and Present Position (London: Tinsley Bros., 1871), 14-15.

118 Ibid., 15.

119 Disraeli, Curiosities of Literature, $\mathrm{x}$.

120 Watts, "Authorship", 486.

121 See for example the "Moon Hoax" of 1834, in Karen Roggenkamp, Narrating the News: New Fournalism and Literary Genre in Late-Nineteenth Century American Newspapers and Fiction (Kent, OH: Kent State University Press, 2005), 1-19.

122 On literary forgery, see Ian Haywood, The Making of History: A Study of the Literary Forgeries of James Macpherson and Thomas Chatterton in Relation to Eighteenth-Century Ideas of History and Fiction (London: Associated University Presses, 1986); Kenneth Ruthven, Faking Literature (Cambridge: Cambridge University Press, 2001).

123 Betty Schellenberg, Literary Coteries and the Making of Modern Print Culture 1740-1790 (Cambridge: Cambridge University Press, 2016), 26-44.

124 Wrestiana, "A Mock-Heroic Historical Romance", p. 187, Bedfordshire \& Luton Archives Service (FAC 11/2).

${ }^{125}$ John Lawry to Yorke, 6 October 1743, Add. MS 35605, f. 163r.

${ }^{126}$ Jemima Yorke to Catherine Talbot, 21 July 1748, Bedfordshire and Luton Archives and Records Service, Lucas Archive: L 30/9a/5/84-89.

127 Kate Loveman, Reading Fictions, 1660-1740: Deception in English Literary and Political Culture (Aldershot: Ashgate, 2008), p. 47.

128 William Coxe, Catalogue of the Manuscripts in the Possession of the Earl of Hardwicke ([London?], 1794), printed, not published, p. 8. The catalogue locates them at "Folios: Volume 71, p. 10": not traced.

129 The Times, 20 February 1899.

130 Rev. Westley Hall, "Catalogue of Rev Thomas Birch Manuscripts”, 1772, Add Ms 4478A, No. 225.

131 Samuel Ayscough, comp., A Catalogue of the Manuscripts Preserved in the British Museum Hitherto Undescribed (London: printed for the compiler by John Rivington, 1782), 219, iv, 218.

132 Disraeli, Curiosities of Literature, ix-x.

133 Thomas Carte, A Full Answer to the Letter from a By-stander (London: printed for J. Robinson at the Golden Lyon, 1742).

134 Thomas Carte, A General History of England, 4 vols. (London: printed for the author and sold by J. Hodges, 1747-1755).

135 Birch to Yorke, 30 September 1742, Add Mss 35396, ff. 70r-v.

136 Yorke to Birch, 7 October 1742, Add Mss 35396, f. 75r.

137 Birch to Yorke, 30 September 1742, Add Mss 35396, ff. 70r-v.

138 Birch to Yorke, 23 October 1742, Add Mss 35396, f. 78r; William Pulteney and Corbyn Morris, $A$ Proper Answer to The By-Stander (London: printed for T. Cooper at the Globe, 1742).

139 Raymond, "Introduction: Newspaper, Forgeries, and Histories", 3. 